EVALUASI, 4 (1), Maret 2020, ISSN 2580-3387 (print) |

ISSN 2615-2886 (online)

Homepage : http://e-journal.staima-alhikam.ac.id/index.php/evaluasi

DOI : : http://doi.org/10.32478/evaluasi.v4i1.356

Article type : Book Review

\title{
Visi Dan Misi Menurut Fred R. David Dalam Perspektif Pendidikan Islam
}

\section{Citra Ayu Anisa}

Rahmatullah

STAI Ma'had Aly Al-Hikam Malang

\begin{abstract}
The focus of this research is on an effort to describe the vision and mission based on the views of Fred R. David, which is then reviewed and described the vision and mission with the perspective of Islamic education. The method used in writing this journal work is literature study by studying, and reviewing from the literature of Fred R. David and other literature related to the theme of this paper. In this journal work, vision and mission are one basic concept in starting a management strategy that will always be related to one another. In the perspective of Islamic education the vision and mission are also interpreted the same as that, because in the vision contains the ideals or goals of victory needed by Islamic educational institutions to be able to continue to develop and improve, while the mission contains activities planned to realize the ideals or goal of Islamic educational institutions. From the perspective of Islamic education, the vision and mission have their own concentration, which is the balance between the development of science and technology (Science and Technology) with the development of Islamic morals in attitude and behavior. The results obtained from the literature study in this journal are 11 (eleven) things that are divided in the preparation of the vision and the preparation of the mission if using the perspective of Islamic education. In the vision of the goals of educational institutions into the future, long-term but also has a time limit, focus on the quality and morals of students, participation of all members, and a vision that is easy to understand. And on the mission, namely content that supports the vision, in accordance with the goals and national education programs, focus on fostering the ability and planting of
\end{abstract}

70 Email: citraayuanisa@gmail.com, Rahmat19@gmail.com

EVALUASI: Jurnal Manajemen Pendidikan Islam is licensed under

The CC BY License (https://creativecommons.org/licenses/by-sa/4.0/) 
EVALUASI, 4 (1), Maret 2020, ISSN 2580-3387 (print) |

ISSN 2615-2886 (online)

Homepage : http://e-journal.staima-alhikam.ac.id/index.php/evaluasi

DOI $\quad$ : http://doi.org/10.32478/evaluasi.v4i1.356

Article type : Book Review

morality, long-term, medium and short term, participation of all members, and a clear mission arrangement

Keywords: Vision and Mission, Islamic Education Perspective.

\begin{abstract}
Abstrak
fokus penelitian ini pada usaha mendeksripsikan visi dan misi berdasarkan pandangan Fred R. David, yang kemudian ditelaah kembali serta dideskripsikan visi dan misi dengan perspektif pendidikan Islam. Metode yang digunakan dalam penulisan karya jurnal ini adalah studi pustaka dengan mempelajari, dan menelaah kembali dari literatur karya Fred $R$. David dan literatur - literatur lain yang terkait dengan tema karya tulis ini. Dalam karya jurnal ini, visi dan misi merupakan satu konsep dasar dalam memulai manajemen strategi yang akan selalu berkaitan antara satu sama lain. Dalam perspektif pendidikan Islam visi dan misi juga diartikan sama dengan hal tersebut, karena dalam visi mengandung cita - cita atau goal kemenangan yang dibutuhkan lembaga pendidikan Islam untuk bisa terus berkembang dan meningkat, sedangkan misi mengandung kegiatan - kegiatan yang direncanakan untuk mewujudkan cita - cita atau goal dari lembaga pendidikan Islam. Pada perspektif pendidikan Islam memandang visi dan misi memiliki konsentrasi tersendiri yaitu keseimbangan antara pembinaan IPTEK (IImu Pengetahuan dan Teknologi) dengan pembinaan akhlak islam dalam bersikap dan bertingkah laku. Hasil yang diperoleh dari studi pustaka pada jurnal ini terdapat 11 (sebelas) hal yang terbagi dalam penyusunan visi dan penyusunan misi jika mengunakan perspektif pendidikan Islam. Pada visi yaitu goal lembaga pendidikan ke masa depan, berjangka waktu panjang tetapi juga memiliki batasan waktu, fokus pada kualitas dan akhlak peserta didik, partisipasi seluruh anggota, dan visi yang mudah dipahami. Dan pada misi yaitu konten yang mendukung visi, sesuai dengan tujuan maupun program pendidikan nasional, fokus pada pembinaan kemampuan dan penanaman akhlaqul karimah, berjangka waktu panjang, sedang serta pendek, partisipasi seluruh anggota, dan susunan misi yang jelas.
\end{abstract}

Kata Kunci : Visi dan Misi, Perspektif Pendidikan Islam. 
ALUASI, 4 (1), Maret 2020, ISSN 2580-3387 (print) |

ISSN 2615-2886 (online)

Homepage : http://e-journal.staima-alhikam.ac.id/index.php/evaluasi

DOI : : http://doi.org/10.32478/evaluasi.v4i1.356

Article type : Book Review

\section{Pendahuluan}

Gagasan bidang studi tentang manajemen, dapat dikatakan berasal dari pemikiran para ahli yang berorientasi pada awal kemunculannya yang berfokus pada instansi bisnis atau lembaga bernilai profit disebut dengan perusahaan. Perusahaan dalam hal ini, mengunakan kata manajemen sebagai upaya pengelolaan dalam menjalankan seluruh kegiatan di perusahaan tersebut. Usaha manajemen dalam suatu perusahaan merupakan faktor terpenting untuk mempertahankan dan meningkatkan keuntungan serta eksistensi dari perusahaan tersebut, sehingga menjadikan manajemen sebagai aktifitas kunci untuk membawa perusahaan untuk mencapai kesuksesan. Melihat hal ini, penerapan manajemen dalam lembaga profit memegang peranan penting untuk menjamin lembaga profit tersebut mendapatkan keuntungan baik secara materiil maupun kejayaan bagi lembaga profit tersebut.

Salah satu bagian studi manajemen yang menjadi fokus pekerjaan di lembaga profit atau bisnis adalah manajemen strategi. Penerapan manajemen strategi dilakukan dengan mengacu pada nilai - nilai persaingan bebas antar lembaga profit atau bisnis, dengan mengupayakan dayaguna secara keseluruhan dari sumber daya yang dimiliki untuk mencapai tujuan lembaga profit atau bisnis tersebut. Tujuan dari lembaga profit atau bisnis ini, cenderung pada mempertahankan serta meningkatkan eksistensi dalam jangka waktu yang panjang, dan berorientasi pada kemampuan pendapatan laba yang berkelanjutan. Oleh karena itu, manajemen strategi menjadi bidang studi yang telah lama dikembangkan secara teoritis dan praktis di lingkungan lembaga profit (perusahan dan industri bisnis). ${ }^{1}$

Manajemen strategi telah dikenal secara umum pada lembaga profit (perusahaan atau industri bisnis), sebagai upaya untuk mewujudkan tujuan dari lembaga profit tersebut. Pada lembaga non-profit khususnya pada lembaga pendidikan, penerapan manajemen strategi masih dipandang sebagai paradigma baru, yang masih dicoba diterapkan di lembaga non profit atau pendidikan. Penerapan manajemen strategi pada lembaga pendidikan tidak bisa dilakukan secara keseluruhan, seperti halnya pada penerapan manajemen strategi di lembaga profit.

\footnotetext{
${ }^{1}$ Hadari Nawawi, Manajemen Strategik Organisasi Non Profit Bidang Pemerintahan Dengan Ilustrasi Di Bidang Pendidikan, (Cet. II; Yogyakarta: Gadjah Mada University Press, 2003), hlm. 145.
} 
EVALUASI, 4 (1), Maret 2020, ISSN 2580-3387 (print) |

ISSN 2615-2886 (online)

Homepage : http://e-journal.staima-alhikam.ac.id/index.php/evaluasi

DOI : : http://doi.org/10.32478/evaluasi.v4i1.356

Article type : Book Review

Pada lembaga yang bernilai non-profit, dalam hal ini lembaga pendidikan islam diperlukan penyesuaian berbagai aspek yang ada pada penerapan manajemen strategi dan lembaga pendidikan tersebut, sehingga dapat menyusun kebijakkan dalam manajemen strategi sesuai dengan nilai - nilai serta tujuan yang ada pada lembaga pendidikan islam. Perbedaan yang membuat manajemen strategi tidak dapat diterapkan secara keseluruhan seperti halnya pada lembaga profit pada lembaga non-profit, dikarenakan nilai-nilai yang berbeda antara lembaga profit dan non-profit. Lembaga nonprofit didasari oleh nilai - nilai pengabdian, kemanusiaan serta pencapaian kepuasaan yang tidak bersifat materiil. ${ }^{2}$

Perbedaan dalam penerapan manajemen strategi sangat terlihat jelas, ketika hal tersebut mebandingkan antara penerapan pada lembaga profit / perusahaan dengan penerapan pada lembaga non - profit / pendidikan islam. Hal ini tampak jelas pada orientasi dalam menentukan visi dan misi yang dijadikan tujuan utama untuk dicapai oleh lembaga tersebut. Visi dan Misi pada lembaga profit / perusahaan berorientasi pada pencapaian keuntungan secara maksimal dengan usaha, biaya, dan waktu yang seefektif serta seefisien mungkin, sedangkan Visi dan Misi pada lembaga non - profit berorientasi pada pencapaian keuntungan yang tidak tampak secara langsung pada saat itu juga dan tidak terpaku pada keuntungan materiil, karena yang dianggap penting dan menjadi prioritas bagi lembaga non - profit adalah mensejahterakan para anggota sehingga menghasilkan pengabdian dan ketulusan para anggota pada lembaganya.

Orientasi visi dan misi yang sangat berbeda pada kedua kategori lembaga tersebut, bukan berarti mengubah arti atau lingkup dari visi dan misi tersebut, hanya saja pada terget yang ditentukan pada visi dan misi yang berbeda cara pandangannya antara dua kategori lembaga. Visi dan misi tetap dipandang sebagai hal yang dijadikan penentu keberhasilan dari sebuah lembaga, apabila dapat mewujudkan visi dan misi sesuai dengan ketentuan yang telah lembga sendiri telah putusan. Oleh karena itu, dalam karya tulis ini akan dipaparkan mengenai Konsep Visi dan Misi dari pendapat seorang ahli yaitu Fred R. David yang kemudian dideskripsikan dengan perspektif pendidikan.

${ }^{2}$ Hadari Nawawi, Manajemen Strategik Organisasi Non Profit..., (Cet. II; Yogyakarta: Gadjah Mada University Press, 2003), hlm. 146. 
ALUASI, 4 (1), Maret 2020, ISSN 2580-3387 (print) |

ISSN 2615-2886 (online)

Homepage : http://e-journal.staima-alhikam.ac.id/index.php/evaluasi

DOI : : http://doi.org/10.32478/evaluasi.v4i1.356

Article type : Book Review

\section{Pembahasan}

Visi

Visi dikatakan sebagai kornitrnen yang ditetapkan oleh suatu organisasi. Penyataan tersebut senada dengan yang dikernukan oleh Fred R. David dalam karya tulis beliau, yaitu :

"A vision statement should answer the basic question, "What do we want to become?". The vision statement should be short, preferably one sentence, and as many managers as possible should have input into developing the statement. It is especially important for managers and executives in any organization to agree on the basic vision that the firm strives to achieve in the long term. ${ }^{3 \prime \prime}$

Berdasarkan pernyataan tersebut, dikatakan bahwa visi merupakan bentuk statement yang mengandung jawaban dan pengambaran tentang suatu kondisi maupun citra perusahaan atau lembaga yang ingin diwujudkan pada masa yang akan datang, atau singkatnya statement visi dengan kata lain harus dapat menjawab kalimat, "Kita ingin menjadi apa?". Statement visi harus dibuat dengan mengunakan kalimat yang singkat tetapi juga harus jelas dalam menyatakan statement dari visi tersebut dan juga berjangka waktu panjang tetapi terdapat batasan waktu di dalamnya. Visi dalam tanggung jawab penyusunannya diberikan pada pimpinan atau manajer puncak dalam mengambil keputusan terakhir, tetapi tetap diutamakan keterlibatan seluruh anggota dalam memberikan pandangan serta masukkan, sehingga statement yang ingin dijadikan visi perusahaan atau lembga dapat disepakati, diterima, dipahami dan dilaksanakan oleh seluruh anggota perusahaan atau lembaga tersebut.

Visi pada bidang bisnis atau profit dapat menerapkan pandangan visi tersebut secara keseluruhan dan membentuknya dalam statement visi yang bernilai profit dan berfokus pada pendapatan laba sebesar - besarnya. Tetapi lain halnya, apabila statement visi tersebut akan diterapkan pada bidang pendidikan islam. Penyusunan statement visi harus dilakukan dengan cara mengadopsi dari dasar visi yang pada dasarnya ditujukan untuk bidang bisnis atau profit, kemudian mengadaptasikannya pada fokus atau orientasi dasar dari pendidikan islam itu sendiri yang bernilai non - profit artinya tidak mengutamakan pendapatan laba secara materiil, cepat, sebesar - besarnya.

\footnotetext{
${ }^{3}$ Fred R. David, Strategic Management Concepts And Cases, (Ed. XIII; New Jersey: Prentice Hall, 2011), hlm. 43.
} 
EVALUASI, 4 (1), Maret 2020, ISSN 2580-3387 (print) |

ISSN 2615-2886 (online)

Homepage : http://e-journal.staima-alhikam.ac.id/index.php/evaluasi

DOI : : http://doi.org/10.32478/evaluasi.v4i1.356

Article type : Book Review

Pengadaptasian penyusunan statement visi pada perspektif pendidikan Islam, dapat dilihat dan dicermati dari visi pendidikan yang telah ditetapkan oleh pemerintah dalam Undang - Undang yang mengatur sistem pendidikan nasional di Indonesia yang berbunyi :

"Visi pendidikan nasional adalah mewujudkan sistem pendidikan sebagai pranata sosial yang kuat dan berwibawa untuk memberdayakan semua warga negara Indonesia agar berkembang menjadi manusia yang berkualitas sehingga mampu dan proaktif menjawab tantangan zaman yang selalu berubah. ${ }^{4 \prime}$

Statement visi pendidikan nasional tersebut dapat dicermati serta dipahami bahwa dalam perspektif pendidikan Islam, visi sama halnya dalam bidang bisnis yang dipergunakan untuk landasan dan tujuan (goal) utama dalam menetapkan seluruh kebijakkan, kegiatan dan disesuaikan dengan nilai - nilai Islam. Dengan penyesuaian visi secara dasar dengan nilai - nilai yang terdapat pada bidang pendidikan Islam, sehingga didalam bidang pendidikan islam juga terjadi usaha manajemen strategi untuk menghadapi masa yang akan datang dan dapat mempertahankan nilai - nilai yang diajarkan dalam Islam. Tetapi yang membedakan penyusunan visi dalam bidang pendidikan Islam adalah orientasi serta fokus dari tujuan utama yang ingin dicapai merupakan goal yang tidak bersifat komersial serta mengesampingkan laba materiil.

Persepktif pendidikan islam dalam memahami visi, dapat dibaca serta dipahami dalam Q.S Al - Alaq pada Ayat 1 - 5, yang berbunyi :

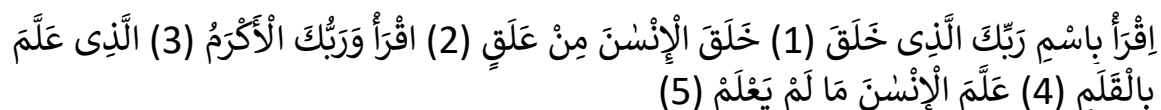

Artinya : "Bacalah dengan (menyebut) nama Tuhamu Yang Menciptakan \{1\}, Dia telah menciptakan manusia dari segumpal darah $\{2\}$, Bacalah, dan Tuhanmulah Yang Maha Mulia \{3\}, Yang mengajar (manusia) dengan pena $\{4\}$, Dia mengajarkan manusia apa yang tidak diketahuinya $\{5\} . "$

Berdasarkan penggalan ayat tersebut, dapat diketahui bahwa visi pendidikan islam adalah memberikan pembelajaran agar individu dapat

${ }^{4}$ Peraturan Pemerintah Nomor 19 Tahun 2005 
ALUASI, 4 (1), Maret 2020, ISSN 2580-3387 (print) |

ISSN 2615-2886 (online)

Homepage : http://e-journal.staima-alhikam.ac.id/index.php/evaluasi

DOI : : http://doi.org/10.32478/evaluasi.v4i1.356

Article type : Book Review

memahami hakikatnya sebagai manusia dan membina akal dan jiwa manusia dengan ilmu pengetahuan dan akhlak atau etika.

Oleh karena itu, dapat digambarkan perbedaan visi dalam perspektif bisnis dan perspektif pendidikan Islam, sebagai berikut:
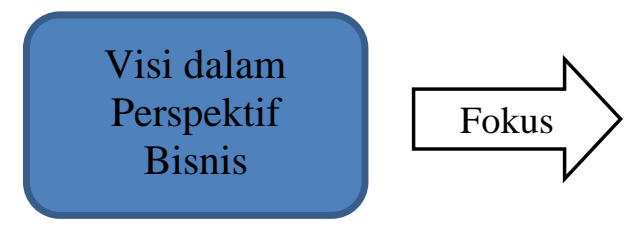

Goal yang bersifat Komersil \& Mendatangkan Laba Maksimal, berjangka panjang

Visi dalam

Perspektif

Pendidikan

Islam

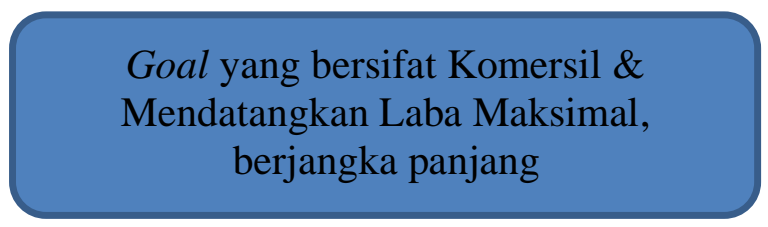

Goal yang bersifat Non-Komersil \& pemenuhan kebutuhan Intelektual dan

Akhlak yang harus dimiliki Peserta

Didik, serta berjangka panjang

Gambar 1. Perbedaan Visi Perspektif Bisnis dan Pendidikan Islam

Berdasarkan hal - hal tersebut, dapat dikatakan bahwa visi dalam perspektif pendidikan Islam memiliki beberapa hal - hal yang harus diperhatikan ketika akan mengawali penyusunan visi pada lembaga pendidikan Islam, antara lain :

1. Mendeskripsikan goal Lembaga Pendidikan Islam ke masa depan.

Statement Visi harus mengandung kalimat yang mengambarkan keadaan atau tujuan yang ingin diwujudkan di waktu kedepan, sehingga diperlukan kemampuan manajer puncak dalam prediksi perkembangan IPTEK (Ilmu Pengetahuan \& Teknologi) kedepannya dan serta menunjang terwujudnya visi pendidikan nasional yang telah ditentukan oleh pemerintah.

2. Memiliki jangka waktu yang panjang beserta batasan waktu yang jelas.

Statement Visi dibuat agar memfokuskan seluruh kegiatan pendidikan pada landasan serta tujuan yang satu, sehingga diperlukan jangka waktu serta batasan waktu dalam mewujudkan visi tersebut. Hal ini dapat dijadikan sebagai tolak ukur dalam pengembangan visi lembaga pendidikan Islam dalam menyesuaiakan diri dengan perubahan zaman.

3. Menitikberatkan pada kualitas dan akhlak dari Peserta Didik. 
EVALUASI, 4 (1), Maret 2020, ISSN 2580-3387 (print) |

ISSN 2615-2886 (online)

Homepage : http://e-journal.staima-alhikam.ac.id/index.php/evaluasi

DOI $\quad$ : http://doi.org/10.32478/evaluasi.v4i1.356

Article type : Book Review

Statement Visi lembaga pendidikan Islam tidak boleh bernilai komersil serta tidak berorientasi pada hal - hal yang bersifat mencari laba atau keuntungan materiil. Visi lembaga pendidikan Islam harus berfokus pada penyesuaian antara program pendidikan dengan perkembangan kebutuhan zaman serta pembinaan dengan nilai - nilai islam sebagai batasan dan aturan dalam menyikapi segala hal yang dilakukan, sehingga dapat mencetak peserta didik yang memiliki kualitas yang memenuhi perkembangan kebutuhan zaman dan tetap memiliki akhlak yang baik dalam berinteraksi dengan masyarakat serta menghadapi perubahan.

4. Melibatkan seluruh anggota lembaga.

Penyusunan statement visi bukan hanya terpaku pada pandangan pemimpin atau manajer puncak. Visi dengan kualitas yang baik adalah visi yang terbentuk dari dari berbagai macam pandangan dari setiap elemen atau hirarki keanggotaan, yang kemudian didiskusikan dan disepakati sebagai tujuan bersama. Dengan keterlibatan setiap elemen keanggotaan diharapkan visi tersebut dapat dijadikan komitmen bersama yang ingin sama - sama diwujudkan, demi kebaikkan lembaga pendidikan Islam.

5. Pernyataan yang mudah dipahami.

Hal yang tidak kalah penting dalam penyusunan statement visi adalah penggunaan kalimat yang singkat dan jelas, sehingga dapat mudah diinformasikan serta dipahami oleh seluruh anggota maupun masyarakat sekitar yang melihat dan mengamati lembaga pendidikan tersebut.

Misi

Misi dapat dikatakan sebagai rincian hal - hal pokok yang dapat menunjang terwujudnya visi. Fred R. David dalam karya tulis beliau yang merujuk pada Peter Drucker dalam memahami pernyataan misi, yaitu :

"Drucker says that asking the question "What Is Our Business?" is synonymous with asking the question "What Is Our Mission?". The Mission statement is a declaration of an organization's "Reason For Being". The mission statement reveals what an organization want to be and whom it want to serve. A clear mission statement is essential for effectively establishing objectives and formulating strategies. Drucker also added that business mission is the foundation for priorities, strategies, plans, and work assignments. It is the starting point for the 
ALUASI, 4 (1), Maret 2020, ISSN 2580-3387 (print) |

ISSN 2615-2886 (online)

Homepage : http://e-journal.staima-alhikam.ac.id/index.php/evaluasi

DOI : : http://doi.org/10.32478/evaluasi.v4i1.356

Article type : Book Review

design of managerial jobs and, above all, for the design og managerial structures. ${ }^{\text {" }}$

Berdasarkan pernyataan tersebut, dikatakan bahwa misi merupakan susunan rencana pokok yang mendeskripsikan alasan perusahaan atau lembaga tersebut dibuat dan ditujukan pada isu yang menjadi fokus perusahaan atau lembaga tersebut. Misi tersusun dari hal - hal pokok yang ingin dilakukan dan dicapai oleh sebuah perusahaan atau lembaga untuk menunjang keterwujudan visi (goal utama) yang telah ditetapkan. Statement - statement misi yang disusun secara jelas, sangat dibutuhkan dan penting dalam menetapkan kegiatan - kegiatan teknis serta dalam merumuskan strategi secara efektif.

Perumusan strategi yang merupakan salah satu proses terpenting dalam manajemen strategi membutuhkan kekuatan visi dan misi yang jelas untuk memulai perumusan strategi tersebut. Drucker yang merupakan pelopor manajemen modern, mengatakan juga bahwa misi dalam bidang bisnis merupakan dasar titik fokus dan prioritas dalam penentuan strategi, rencana, dan pengaturan pembagian tugas serta tanggung jawab kerja. Statement misi memegang peranan awal dan dasaar dalam mendesain struktur manajerial dan pekerjaan manajerial dalam perusahaan.

Penerapan bentuk misi yang telah dipaparkan, sudah diterapkan pada bidang bisnis yang memang menjadi fokus isu dalam pengembangan ilmu manajemen pada masa awal penerapannya. Senada dengan orientasi dari statement visi yang apabila diterapkan pada bidang pendidikan Islam maka memfokuskan pada hal - hal yang bernilai non - profit, sama halnya pada bentuk statement - statement misi apabila diterapkan pada bidang pendidikan Islam. Misi yang disusun pada bidang pendidikan Islam atau lingkungan lembaga non - profit memang memperlukan proses adopsi nilai misi yang sistematis untuk mencapai visis dan meningkatkan kualitas, tetapi juga diperlukan usaha adaptasi terhadap perkembangan pandangan baru tersebut karena perbedaan orientasi keuntungan yang berlawan antara keuntungan bernilai profit dengan keuntungan bernilai non - profit.

Pengadaptasian bentuk statement - statement misi pada perspektif pendidikan Islam pada dasarnya dapat melihat dan mencermati misi yang telah ditetapkan oleh pemerintah, mengenai 7 (tujuh) Misi Pendidikan

${ }^{5}$ Fred R. David, Strategic Management Concepts And Cases, (Ed. XIII; New Jersey: Prentice Hall, 2011), hlm. 44. 
EVALUASI, 4 (1), Maret 2020, ISSN 2580-3387 (print) |

ISSN 2615-2886 (online)

Homepage : http://e-journal.staima-alhikam.ac.id/index.php/evaluasi

DOI $\quad$ : http://doi.org/10.32478/evaluasi.v4i1.356

Article type : Book Review

Nasional yang tercantum pada Undang - Undang tentang Sistem Pendidikan Nasional di Indonesia ${ }^{6}$, sebagai berikut :

1. Mengupayakan perluasan dan pemerataan kesempatan memperoleh pendidikan yang bermutu bagi seluruh rakyat Indonesia.

2. Meningkatkan mutu pendidikan yang memiliki daya saing di tingkat nasional, regional, dan internasional.

3. Meningkatkan relevansi pendidikan dengan kebutuhan masarakat dan tantangan global.

4. Membantu dan memfasilitasi pengembangan potensi anak bangsa secara utuh sejak usia dini sampai akhir hayat dalam rangka mewujudkan masyarakat belajar.

5. Meningkatkan kesiapan masukan dan kualitas proses pendidikan untuk mengoptimalkan pembentukkan kepribadian yang bermoral.

6. Meningkatkan keprofesonalitas dan akuntabilitas lembaga pendidikan sebagai pusat pembudayaan ilmu pengetahuan, keterampilan, pengalaman, sikap, dan nilai berdasarkan standar yang bersifat nasional dan global.

7. Mendorong peran serta masyarakat dalam peyelenggaraan pendidikan berdasarkan prinsip otonomi dalam konteks Negara Kesatuan Republik Indonesia (NKRI).

Statement - statement misi dari pendidikan nasional yang telah ditetapkan oleh pemerintah Indonesia dapat diidentifikasikan bahwa fokus kegiatan maupun program pendidikan yang akan dikembangkan mengikuti statement misi yang telah ditetapkan. Dari statement - statement misi tersebut terlihat bahwa tidak ada perhatian dari misi tersebut pada hal - hal yang bersifat pada pendapatan laba ataupun hal - hal yang bernilai komersil. Dari hal tersebut, dapat dipahami bahwa misi pada bidang pendidikan, memiliki kesamaan cara penyusunan statement misi tetapi yang berbeda pada orientasi yang pada bidang bisnis bersifat komersial dan menghitung persentase laba yang didapatkan, sedangkan orientasi pada bidang pendidikan peningkatan kualitas pendidikan serta peserta didik dalam menghadapi perkembangan zaman yang semakin meningkat.

${ }^{6}$ Peraturan Pemerintah Nomor 19 Tahun 2005 
ALUASI, 4 (1), Maret 2020, ISSN 2580-3387 (print) |

ISSN 2615-2886 (online)

Homepage : http://e-journal.staima-alhikam.ac.id/index.php/evaluasi

DOI : : http://doi.org/10.32478/evaluasi.v4i1.356

Article type : Book Review

Dalam persepktif Islam, pemahaman mengenai misi dapat dipahami dalam Q.S An - Nahl pada Ayat 125, yang berbunyi :

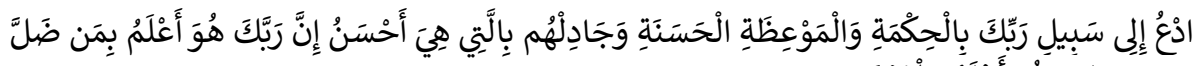

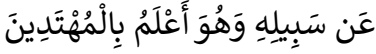

Artinya : "Serulah (manusia) kepada jalan Tuhanmu dengan hikmah dan pengajaran yang baik, dan berdebatlah dengan mereka dengan cara yang baik. Sesungguhnya Tuhanmu, Dialah yang lebih mengetahui siapa yang sesat dari jalan - Nya dan Dialah yang lebih mengetahui siapa yang mendapat petunjuk."

Berdasarkan ayat tersebut, misi pendidikan Islam harus mengandung ide - ide pokok yang mengedepankan pemberian pengajaran yang baik dan nilai - nilai etika, sopan santun yang bukan hanya dilakukan oleh peserta didik terhadap pendidik, tetapi juga sebaliknya. Oleh karena itu, pada perspektif pendidikan Islam dalam memahami misi dapat dikatakan sama dengan orientasi misi pada bidang pendidikan nasional yang telah ditetapkan pemerintah. Dari orientasi misi pendidikan yang menekankan pada statement - statement misi yang bernilai non - profit, pada perspektif pendidikan Islam ditambahkan nilai - nilai Islam dalam statement misi yang ingin dilaksanakan oleh lembaga pendidikan Islam.
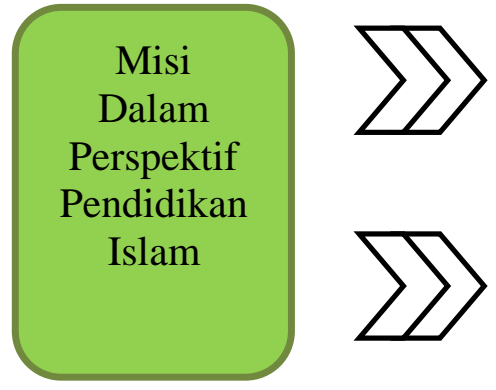

Ide - Ide Pokok Penunjang Visi yang bersifat Non-Komersil

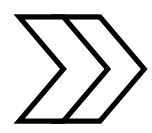

Pemenuhan dan pembinaan kebutuhan kemampuan dan akhlak pada Peserta Didik, berjangka panjang, sedang, pendek

Gambar 2. Misi di Perspektif Pendidikan

Berdasarkan pendapat-pendapat tersebut, dapat dikatakan bahwa misi dalam perspektif pendidikan Islam memiliki hal - hal yang perlu diperhatikan dalam penyusunan statement - statement misi yang akan menjadi fokus seluruh kegiatan teknis dalam suatu lembaga pendidikan Islam, antara lain :

1. Konten yang mendukung visi yang telah ditetapkan pada lembaga. 
EVALUASI, 4 (1), Maret 2020, ISSN 2580-3387 (print) |

ISSN 2615-2886 (online)

Homepage : http://e-journal.staima-alhikam.ac.id/index.php/evaluasi

DOI : $\quad$ http://doi.org/10.32478/evaluasi.v4i1.356

Article type : Book Review

Penyusunan dan penetapan dari misi harus dilakukan untuk mendukung keterwujudnya visi, yang kemudian dapat membantu dalam membuat kegiatan manajerial dan struktur manajerial yang sesuai dengan misi dan mencapai visi yang diinginkan suatu lembaga pendidikan Islam. Sama halnya dengan visi hal yang perlu diutamakan adalah konten atau isi dari misi harus berkonsentrasi utama pada kualitas peserta didik, bukan kepentingan lembaga semata.

2. Ketersesuaian dengan visi, misi, maupun program pendidikan nasional.

Dalam penyusunan misi hal yang tak kalah penting dan menjadi syarat adalah harus adanya kesesuaian misi dengan visi, misi dan program yang telah ditetapkan pemerintah. Hal ini perlu dilakukan untuk membantu pemerintah untuk mewujudkan visi, misi, dan program pendidikan yang ingin dibentuk sedemikian rupa, agar dapat meningkatkan kualitas pendidikan maupun meningkatkan kuualitas warga Negara yang dapat disegani oleh Negara lainnya. Dalam hal ini juga dapat membentuk keselarasan antara kualitas dari pemerintah mengenai pendidikan secara nasional dengan misi yang coba diwujudkan oleh lembaga pendidikan Islam, sehingga antara misi pendidikan dari pemerintah dan lembaga pendidikan Islam dapat saling mendukung satu sama lain.

3. Menitikberatkan pada keseimbangan antara pembinaan kemampuan dan penanaman akhlaqul karimah pada peserta didik.

Sama halnya dengan visi yang harus mengikuti perkembangan zaman dengan tetap menitikberatkan pada pemenuhan kebutuhan dalam membentuk kualitas kemampuan peserta didik yang dapat mengikuti alur dari perkembanga zaman, tetapi tetap memiliki satu pilar (berakhlaqul karimah) yang dapat dijadikan sebagai jati diri dari setiap peserta didik. Hal tersebut lah yang juga harus diperhatikan dalam menyusun misi. Penyusunan misi harus mengutamakan fokusnya pada pembentukkan dan peningkatan kualitas maupun jati diri dari peserta didik, sehingga lembaga pendidikan memang digunakan untuk mencetak peserta didik yang bukan hanya dapat menyesuaikan diri dengan perkembangan dan perubahan zaman tapi juga memiliki kemampuan untuk membatasi diri pada hal - hal yang dapat memberikan dampak yang kurang baik pada diri peserta didik.

4. Memiliki jangka waktu panjang, sedang, dan pendek. 
ALUASI, 4 (1), Maret 2020, ISSN 2580-3387 (print) |

ISSN 2615-2886 (online)

Homepage : http://e-journal.staima-alhikam.ac.id/index.php/evaluasi

DOI : : http://doi.org/10.32478/evaluasi.v4i1.356

Article type : Book Review

Dalam penyusun misi perlu diperhatikan juga didalam isi misi tersebut harus diperhatikan juga pada jangka waktu, yang harus harus mencakup jangka panjang, sedang, dan pendek. Hal tersebut diperlukan karena misi merupakan langkah awal dari penyususnan kegiatan maupun struktur manjerial yang sangat dibutuhkan, agar lembaga pendidikan Islam dapat menyusun kegiatan serta program sesuai urutan priortas yang benar dan teratur.

5. Melibatkan seluruh anggota lembaga.

Pada penyusunan misi juga sebuah keharusan akan keterlibatan seluruh anggota lembaga pendidikan Islam, karena bukan hanya pemimpin lembaga dalam hal ini kepala sekolah yang berkewajiban membuat misi dari lembaga pendidikan Islam. Misi lembaga pendidikan Islam, sesuai dengan penyebutannya sebagai misi lembaga pendidikan Islam peran seluruh anggota lembaga dibutuhkan baik, dalam penyusunan, memahaman, sampai pada pelaksanaan misi tersebut. Dalam pensosialisasian misi, juga kewajiban seluruh anggota lembaga untuk pemberian pemahaman pada seluruh pihak yang tekait atau berhubungan dengan lembaga pendidikan mengenai misi yang dilakukan di lembaga pendidikannya.

6. Susunan serta pernyataan misi yang jelas.

Penyusunan statement - statement dari misi baik susunan maupun rangkaian kata yang digunakan harus jelas dan memiliki fokus yang ingin dilakukan pada tiap statement yang ditetapkan sebagai misi. Rangkaian kata yang jelas dalam menyusun misi bertujuan untuk memudahkan anggota maupun pihak luar anggota untuk memahami apa yang ingin diupayakan oleh lembaga pendidikan. Dan susunan statement statement misi yang harus disusun secara jelas dapat digunakan sebagai langkah awal, yang kemudian dikembangkan menjadi tujuan dan digunakan dalam perumuasan strategi pada lembaga pendidikan Islam.

\section{Konsep Visi Misi}

Dalam pemaparan mengenai konsep visi dan misi, dapat diidentifikasi dan dipahami dari Model Manajemen Strategik menurut Literatur Fred R. David $^{7}$ :

\footnotetext{
${ }^{7}$ Fred R. David, Strategic Management Concepts And Cases, (Ed. XIII; New Jersey: Prentice Hall, 2011), hlm. 45.
} 
EVALUASI, 4 (1), Maret 2020, ISSN 2580-3387 (print) |

ISSN 2615-2886 (online)

Homepage : http://e-journal.staima-alhikam.ac.id/index.php/evaluasi

DOI $\quad$ : http://doi.org/10.32478/evaluasi.v4i1.356

Article type : Book Review

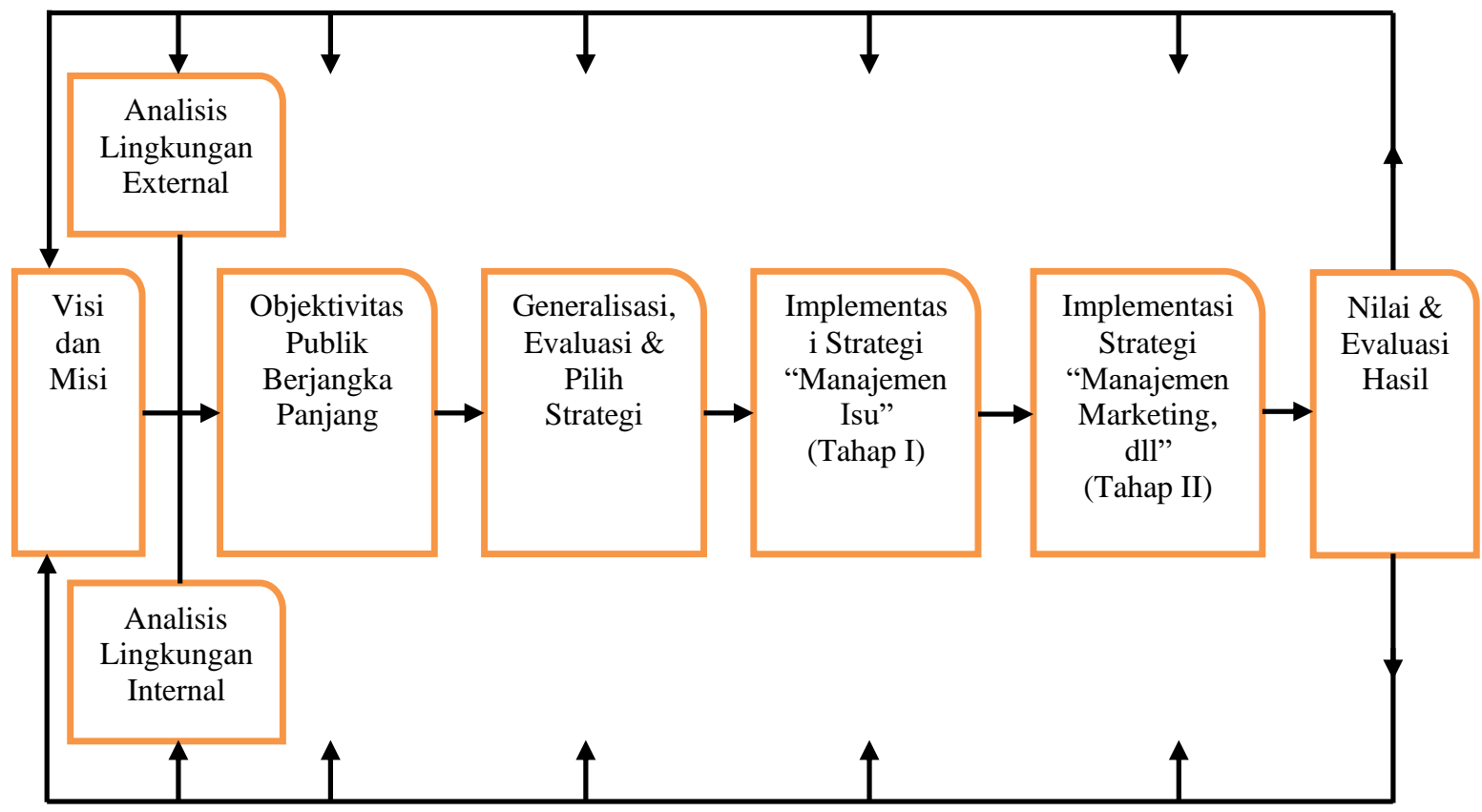

Gambar 3. Model Manajemen Strategik

Dari model manajemen strategi tersebut, dapat diketahui dan dipahami mengenai konsep visi dan misi pada manajemen strategik adalah sebagai bentuk konsep yang dijadikan landasan atau pondasi untuk memulai seluruh aktivitas dalam upaya manajemen strategik di perusahaan maupun lembaga, bahkan di lingkup organisasi yang dalam sekala kecil. Visi dan misi yang berada dalam posisi sebagai landasan atau pondasi yang mendasari upaya manajemen strategik, membuat visi dan misi sangat memberikan pengaruh yang besar terhadap keberhasilan dari upaya penerapan manajemen strategik yang coba dilakukan. Oleh karena itu, dalam proses penyusunan dan penetapan visi dan misi tidak dapat dilakukan secara tergesa - gesa, perlu adanya perhatian khusus dan dilakukan secara teliti dengan pertimbangan matang, serta melibatkan orang - orang atau sumber daya manusia yang menguasai mengenai penyusunan visi dan misi agar didapatkan visi dan misi yang berkualitas.

Visi dan misi bernilai sangat penting bukan hanya sebagai kesatuan konsep yang ada untuk mendasari setiap aktivitas atau kegiatan dalam manajemen strategi. Tetapi hal yang tak bisa dilepaskan dari wajib adanya visi dan misi adalah sebagai usaha control terhadap semua aktivitas 
ALUASI, 4 (1), Maret 2020, ISSN 2580-3387 (print) I

ISSN 2615-2886 (online)

Homepage : http://e-journal.staima-alhikam.ac.id/index.php/evaluasi

DOI $\quad:$ http://doi.org/10.32478/evaluasi.v4i1.356

Article type : Book Review

manajemen strategi. Dengan visi dan misi seluruh aktivitas atau kegiatan manajemen strategi dapat dikontrol dan diarahkan pada satu arah atau target utama yang sama, walaupun pasti pada setiap jiwa anggota perusahaan ataupun lembaga memiliki kepentingan pribadinya sendiri sendiri. Kepentingan pribadi yang dimiliki oleh setiap anggota tidak bisa dihilangkan, tetapi dengan adanya visi dan misi dapat menyatukan berbagai kepentingan - kepentingan pribadi tersebut agar terarah pada pencapaian visi dan misi perusahaan atau lembaga.
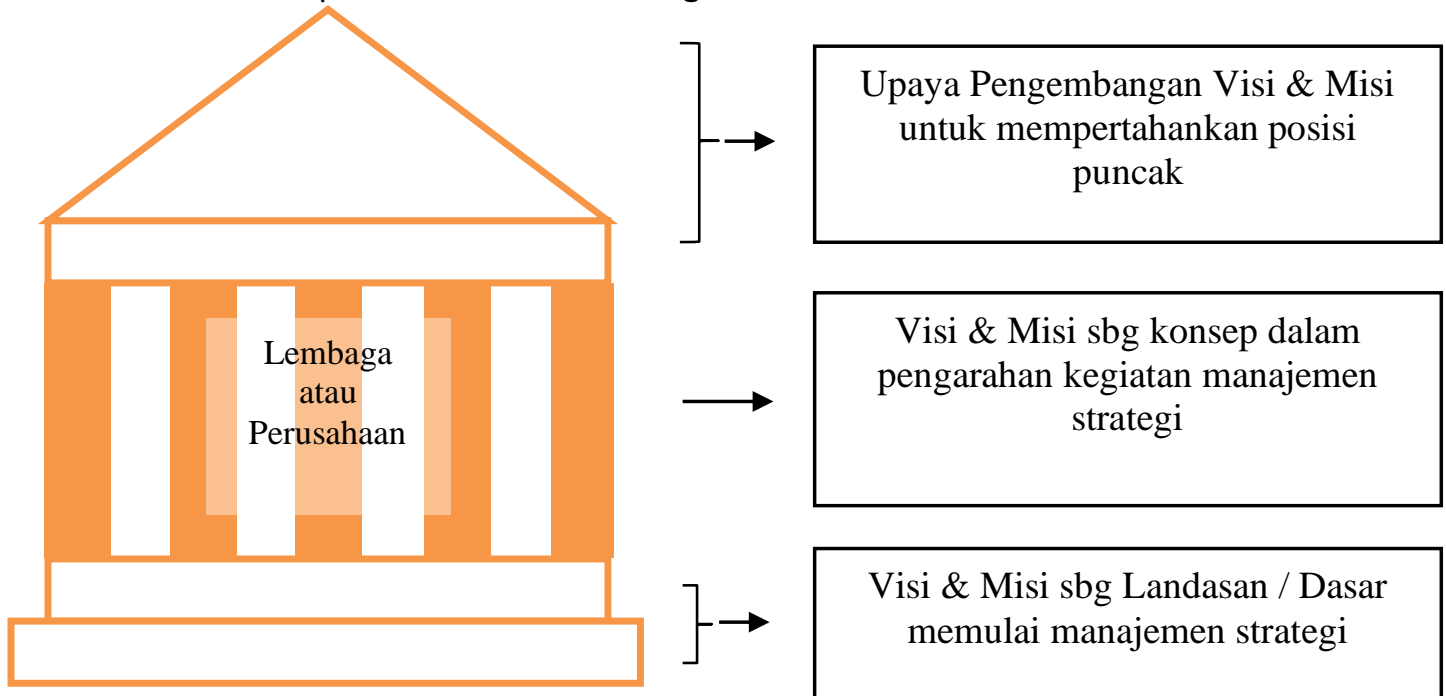

Gambar 5. Ilustrasi Urgensi Lembaga Terhadap Visi dan Misi

Konsep visi dan misi dalam persepktif pendidikan Islam tidak berbeda seperti paparan tentang model manajemen strategi, hanya ketika konsep dari visi dan misi pada penerapan di lembaga pendidikan Islam yang harus selalu diutamakan adalah orientasi dari konsep visi dan misi yang wajib bernilai non - profit dan tidak bersifat komersil dengan memperhatikan syarat - syarat dari visi dan misi pada lembaga pendidikan islam.

Oleh karena itu, dapat dikatakan sebagai berikut Konsep Visi dan Misi dalam Persepektif Pendidikan Islam : 
EVALUASI, 4 (1), Maret 2020, ISSN 2580-3387 (print) |

ISSN 2615-2886 (online)

Homepage : http://e-journal.staima-alhikam.ac.id/index.php/evaluasi

DOI : $\quad$ http://doi.org/10.32478/evaluasi.v4i1.356

Article type : Book Review

\section{VISI LEMBAGA PENDIDIKAN ISLAM}

Hal - Hal yang dapat diperhatikan, yaitu:

1. Mendeskripsikan Goal Lembaga Pendidikan Islam Ke Masa Depan

2. Berjangka Waktu Panjang \& Memiliki Batasan Waktu

3. Titik Fokus Pada Kualitas \& Akhlak Peserta Didik

4. Keterlibatan Seluruh Anggota

5. Statement Yang Mudah Dipahami

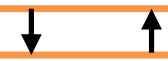

\section{MISI LEMBAGA PENDIDIKAN ISLAM}

Hal - Hal yang dapat diperhatikan, yaitu :

1. Konten Yang Mendukung Visi

2. Ketersesuaian Dengan Visi, Misi, \& Program Pendidikan Nasional

3. Titik Fokus Pembinaan Kemampuan \& Penanaman Akhlaqul Karimah Pada Peserta Didik

4. Berjangka Waktu Panjang, Sedang, \& Pendek

5. Keterlibatan Seluruh Anggota

6. Susunan \& Statement Yang Jelas

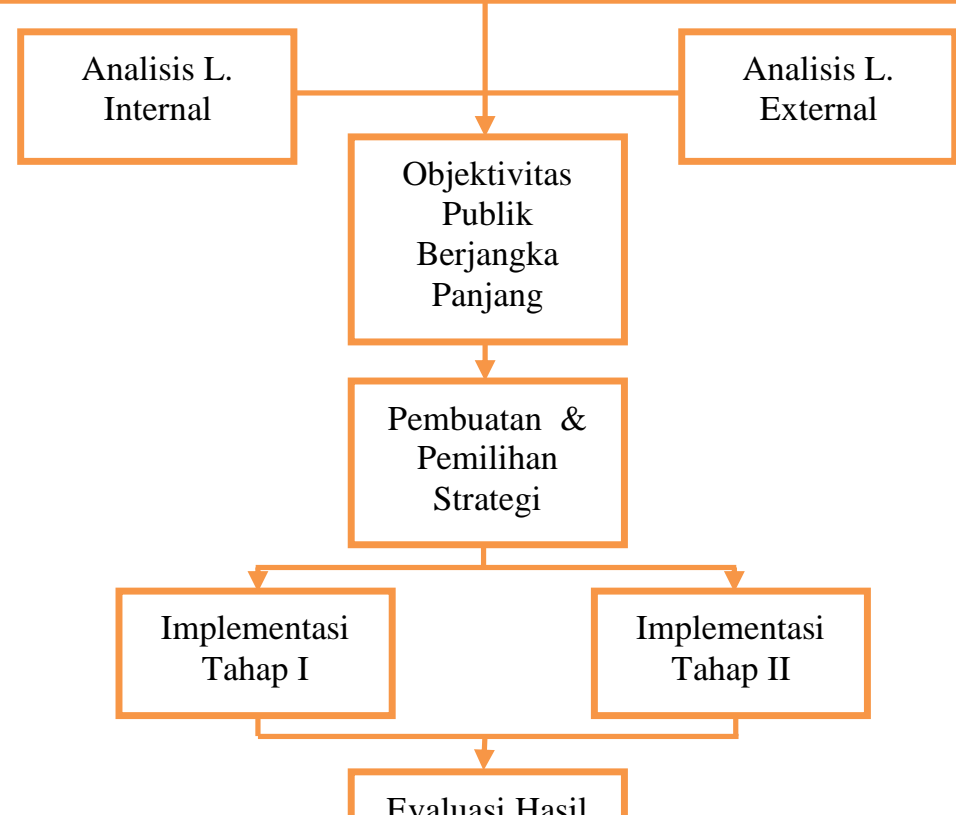

Evaluasi Hasil 
ALUASI, 4 (1), Maret 2020, ISSN 2580-3387 (print) |

ISSN 2615-2886 (online)

Homepage : http://e-journal.staima-alhikam.ac.id/index.php/evaluasi

DOI : : http://doi.org/10.32478/evaluasi.v4i1.356

Article type : Book Review

Gambar 6. Konsep Visi \& Misi Dalam Perspektif Pendidikan

\section{Kesimpulan}

Visi dan misi menurut Fred R. David pada dasarnya memang ditujukan dalam pengaplikasiaan pada manajemen strategik bisnis di perusahaan, dengan tujuan meningkatkan pendapatan keuntungan atau laba dan menguatkan eksistensi dari perusahaan tersebut. Visi dan misi menurut Fred R. David ialah kunci utama dalam pendasaran awal pada usaha manajemen strategik untuk peningkatan laba dan penguatan eksistensi, sehingga dalam menyusunan visi dan misi harus dipikrkan secara matang dan teliti. Dalam proses penyusunan visi dan misi menurut Fred R. David juga dikatakan bahwa pihak yang wajib dilibatkan dalam proses adalah seluruh anggota yang ada dan terlibat dalam perusahaan ataupun lembaga tersebut, sehingga dapat tertetapkannya visi dan misi yang baik dan diharapkan ideal untuk dicapai secara bersama - sama.

Perspektif pendidikan Islam dalam memandang visi dan misi dapat dikatakan tidak jauh berbeda dari pandangan Fred R. David, tetapi dalam orientasi visi dan misi yang memang sangat berbeda dan dijadikan point mutlak yang harus diperhatikan dalam menyusunan visi dan misi. Point mutlak tersebut salah satunya yang dijadikan konsentrasi utama dalam karya ini adalah keuntungan yang bernilai non - profit. Keuntungan non - profit ialah keuntungan yang tidak berfokus pada materiil atau uang secara langsung, cepat dan besar - besaran, tetapi pada keuntungan yang berupa pengabdian, kebanggaan, dan keuntungan lainnya yang akan terlihat dengan berjalannya waktu. Keuntungan non - profit yang seperti itulah yang menjadi konsen dari pendidikan Islam dalam memahami visi dan misi.

Pada hasil akhir dari kajian yang dilakukan di karya ini, penulis menyimpulkan terdapat beberapa hal - hal yang dapat diperhatikan dalam penyusunan visi dan misi. Dalam Visi terdapat 5 (Lima) hal, yaitu : Mendeskripsikan goal Lembaga Pendidikan Islam ke masa depan ; Berjangka waktu panjang dan memiliki batasan waktu ; Titik fokus pada kualitas dan akhlak peserta didik; Keterlibatan seluruh anggota lembaga pendidikan Islam ; Statement yang mudah dipahami. Dan dalam Misi terdapat 6 (Enam) hal, yaitu : Konten yang mendukung visi ; Ketersesuaian dengan dengan visi, misi serta program pendidikan nasional ; Titik fokus pembinaan kemampuan dan penanaman akhlaqul karimah pada peserta didik ; Berjangka waktu panjang, sedang, pendek; Keterlibatan seluruh anggota Lembaga Pendidikan Islam; Susunan dan statement yang jelas. 
EVALUASI, 4 (1), Maret 2020, ISSN 2580-3387 (print) |

ISSN 2615-2886 (online)

Homepage : http://e-journal.staima-alhikam.ac.id/index.php/evaluasi

DOI $\quad$ : http://doi.org/10.32478/evaluasi.v4i1.356

Article type : Book Review

\section{Daftar Pustaka}

Akdon. 2011. Strategic Management For Educational Management : Manajemen Strategik Untuk Manajemen Pendidikan. Bandung : Alfabeta.

Al-Qur'an al-Karim.

David, R., Fred. 2011. Strategic Management Concepts And Cases. Ed. XIII. New Jersey : Prentice Hall.

Fridiyanto. 2019. Manajemen Strategik : Konsep Bisnis Bagi Lembaga Pendidikan Islam. Cet. I. Batu : Literasi Nusantara.

Khori, Ahmad. Mei 2016. Manajemen Strategik Dan Mutu Pendidikan Islam. Vol. I. No. I. Universitas Islam Nusantara.

Nawawi, Hadari. 2003. Manajemen Strategik Organisasi Non Profit Bidang Pemerintahan Dengan Ilustrasi Di Bidang Pendidikan. Cet. II. Yogyakarta : Gadjah Mada University Press.

Peraturan Pemerintah Republik Indonesia Nomor 19 Tahun 2005.

Rahmatullah. Februari 2018. Prinsip Implementasi Manajemen Strategik Dalam Perspektif Islam. Vol. III. No. II. Qolamuna Jurnal Studi Islam.

Tafsir, Ahmad. 2003. Ilmu Pendidikan Dalam Persepktif Pendidikan Islam. Cet. VII. Bandung : PT. Remaja Rosdakarya.

Taufiqurokhman. 2016. Manajemen Strategik. Cet. I. Jakarta : Fakultas IImu Sosial Dan Ilmu Politik Universitas Prof. Dr. Moestopo Beragama. 